\title{
A Great Step Forward. Lithic Raw Material Procurement and Management among Palaeolithic Hunter-Gatherers in the Basque Crossroads
}

\author{
Maite García-Rojas ${ }^{1}$, Eder Dominguez-Ballesteros ${ }^{1,2}$, Alejandro Prieto ${ }^{1,3}$, Aitor \\ Calvo ${ }^{1,3}$, Aitor Sánchez ${ }^{1}$, Andoni Tarriño ${ }^{1}$, Alvaro Arrizabalaga ${ }^{1}$ \\ 1. Department of Geography, Prehistory and Archaeology, University of the Basque Country (UPV/EHU), \\ Tomás y Valiente s/n. 01006 Vitoria-Gasteiz, Spain. Email: García-Rojas: maite.garciar@ehu.eus; Sánchez: \\ aitor.sanchezl@ehu.eus; Tarriño: antonio.tarrinno@ehu.eus; Arrizabalaga: alvaro.arrizabalaga@ehu.eus \\ 2. Centre Européen de Recherches Préhistoriques de Tautavel, Avenue Léon-Jean Grégory, 66720 Tautavel, \\ France. Email: eder.dominguez@ehu.eus \\ 3. Institute of Prehistory and Protohistory, Department of Classical World and Asian Cultures, Friederich- \\ Alexander University of Erlangen-Nürnberg (FAU). Kochstrasse, 4/18, D-91054 Erlangen, Germany. Email: \\ Prieto: alejandro.de.prieto@fau.de; alejandro.prieto@ehu.eus; Calvo: aitor.calvo@ehu.eus
}

\begin{abstract}
:
This paper is divided into three sections. The first section describes the historiographic evolution of the study of prehistoric lithic raw materials in the Basque Crossroads (in the north of the Iberian Peninsula) during the last three decades. The second section explains the currently available information about geological outcrops of flint in the eastern end of the Cantabrian Mountain range (the BasqueCantabrian Basin), the upper Ebro valley and both sides of the western Pyrenees, in the central part of the northern Iberian Peninsula, as that was the main raw material used by hunter-gatherer groups in the Middle and Upper Palaeolithic. Finally, the last section describes the way in which progress in both aspects of research have enabled the introduction of new concepts and perspectives in the reconstruction of the social and economic dynamics of Palaeolithic hunter-gatherers. This has given rise to an innovative methodology that is able to address and solve important issues, particularly regarding mobility and territoriality patterns of those human groups, allowing the proposal of mobility and territoriality models that, while they will not match exactly the systems used by Upper Palaeolithic communities, represent significant progress in understanding the social and economic dynamics of hunter-gatherer groups.
\end{abstract}

Keywords: flint; Palaeolithic; prehistoric economy; lithic technology; historiography

\section{Introduction}

The study of the raw materials used by Palaeolithic hunter-gatherers is an important aspect of Basque prehistoric archaeology. The western sector of the Pyrenees is a privileged place for the study of raw materials, among other reasons because both sides of the mountain range

Published by the School of History, Classics and Archaeology, University of Edinburgh ISSN: 2055-0472. URL: http://journals.ed.ac.uk/lithicstudies/ 
contain a number of siliceous outcrops that supplied Palaeolithic societies owing to the quality and abundance of their materials. Therefore, this is an exceptional region to develop a methodology enabling more precise definitions of the flint varieties found in the archaeological deposits and to consider the possible management of lithic resources in such a complex area as the Basque crossroads.

In this paper the historiographic issues concerning raw material research at the Basque Country crossroads will be analysed through the critical review of the most relevant archaeological deposits analysed under these perspectives. Afterwards, the level of knowledge about the main siliceous outcrops will be explained. With these two sources of information, changes in the concept of raw material procurement will be explained and a model of territorial management will be proposed through the application of geographical information systems. Although we are still far from possessing a full overview of this matter, the avenues of research currently with greatest potential will be suggested.

In this way, the development of lithic raw material studies on the Basque crossroads will be described but also hypotheses will be put forward about the mobility of the human groups and the management of the territory by Palaeolithic communities. Methodological tools allowing these aspects to be explored in other geographic areas will also be outlined.

\section{Antecedents in raw material studies}

The first references to the study of raw materials used by Upper Palaeolithic communities in the central sector of Cantabrian Spain were published in the late twentieth century (Doggett et al. 1995; Sarabia 1999; Straus et al. 1986). In the Basque Country, through the studies carried out by the research group in the Prehistory Department at the University of the Basque Country, lithic raw materials were established as a strategic research line in the 1990s. As a result of this early research, especially when it is compared with other parts of the Iberian Peninsula, the regional outcrops are now precisely defined and, thanks to current archaeo-petrological studies, we are now in a position to propose different historical reconstructions of hunter-gatherer mobility and territoriality.

From a historiographic viewpoint, the first archaeological references to the identification and definition of siliceous materials in the peninsular Basque Country appeared in studies carried out in the River Rojo valley, in the south-west of Treviño County and Álava, by A. Tarriño, and focused on Later Prehistory (Ortiz et al. 1990). This monograph identifies several siliceous outcrops that are classified in four main types and over 12 varieties, based on their geological context and different petrographic textures.

This geological approach to the identification of siliceous outcrops was adopted in the definition of other areas of interest in Peninsular Basque Country. In this way, the three main flint outcrops that became the points of reference for the study of flint at archaeological sites in the peninsular Basque Country had been established by the late 1990s. These are the aforementioned Treviño-type flint; Flysch flint from Kurtzia in the Barrika area; and Urbasa flint (Baceta 1996; Elorza et al. 1985; Tarriño 1997, 2000; Tarriño \& Aguirre 1997). A little later research succeeded in characterising other types of more local importance, such as Urgonian flint (Tarriño 2001: 60) and Loza flint (Tarriño 2001: 87, 2006: 79) and, in the continental Basque Country north of the Pyrenees, the Bidache and Gaintxurizketa varieties, within the Flysch flint group. It is important to stress the interdisciplinary perspective with which these geological flint studies were approached. Despite the fact that the characterisation was based on stratigraphic, petrological, micro-palaeontological and geochemical criteria, it was specifically oriented towards the determination of the flint in archaeological deposits, therefore, understanding human and postdepositional factors that modify different the flint types (generally in small fragments and often with a patina). 
Consequently, by the end of the century, the first approaches were made to understand the procurement strategies developed or carried out by Upper Palaeolithic groups (Tarriño \& Aguirre 1997). In this century, lithic raw material studies (mainly flint) have been included systematically in reports and publications about archaeological sites. Several researches addressing this issue in hunter-gatherer archaeological sites have been published in the literature Urratxa (Tarriño 1997), Antoliñako Koba (García-Rojas 2014: 401; Tarriño \& Aguirre 1997; Tarriño et al. 1998), Labeko Koba (Tarriño 2000), Aizpea (Tarriño 2002: 52), Urrunaga (Fernández-Eraso et al. 2004, 2005, 2012, 2017), Isturitz (Elorrieta 2015a, 2015b: 99; Simonet 2010: 112; Tarriño et al. 2007a), Irikaitz (Arrizabalaga \& Tarriño 2010) Aranbaltza (Rios-Garaizar et al. 2012), Arlanpe (Rios-Garaizar 2013: 177), Aizkoltxo (García-Rojas 2014: 120), Kukuma (García-Rojas 2014: 235), Baltzola (García-Rojas 2014: 279), Praileaitz I (Tarriño 2017), Berroberria (Elorrieta 2015b: 247; Elorrieta \& Tarriño 2016), Atxoste (Soto 2014: 161), Portugain (Tarriño 2008), Alkerdi (Elorrieta 2010: 114, 2015b: 227), Santimamiñe (Tarriño 2011a), Zatoya (Elorrieta 2015b: 303), Ametzagaina (Arrizabalaga et al. 2014; Calvo 2012, 2019: 347; Calvo et al. 2012), Bolinkoba (Calvo 2019: 195), Amalda (Calvo 2019: 241), Usategi (Calvo 2019: 317), Aitzbitarte III (Calvo 2019: 325; Tarriño 2011b) Gatzarria (Calvo 2012, 2019: 491), and Ventalaperra (Ríos-Garaizar 2016), among others.

At the same time as this research was being undertaken, to the south of the Pyrenees in the continental Basque Country, several publications defined other flint outcrops and characterised this raw material in archaeological assemblages. These referred to Flysch flint varieties in that area, in the Chalosse area in the southern part of The Landes, and the Aquitaine group, where systematic research had been carried out since the late 1980s. These describe both the main outcrops from a geological perspective (Bon et al. 1996; Normand 1987, 1993; Seronie-Vivien et al. 1987) and their application to the knowledge of prehistoric societies (Demars 1982; Foucher 2015; Geneste 1985, 1988; Geneste \& Rigaud 1989; Morala 1984; Simonnet 1981; Turq 1989).

\section{Location and definition of the used siliceous outcrops}

This regional framework of analysis is defined by the dialectical relationship between the location of the usable flint outcrops and the position of the Upper Palaeolithic deposits in which the lithic products from those outcrops have been found. The region thus covers the eastern end of the Cantabrian Mountain range (the Basque-Cantabrian Basin), the upper Ebro valley and both sides of the western Pyrenees, in the central part of the northern Iberian Peninsula. Its boundaries are the Aquitaine Basin to the north, the Ebro valley to the south, the Aragonese Pyrenees to the east, and the Bilbao Fault to the west.

This region is articulated by the Atlantic-Mediterranean watershed as its central axis on an east-west alignment, from Mesa de los Tres Reyes, in the western Pyrenees, to the Sierra Salvada, with altitudes reaching over $1500 \mathrm{~m}$ a.s.l. To the north of the watershed, a series of ranges generally lower than $1000 \mathrm{~m}$ are divided up transversely by the river network, creating a complex relief. To the south, the relief is gentler, allowing longer river systems than in the north. The main river basins draining to the Mediterranean are the Rivers Zadorra, Ega and Arga, all of them tributaries of the Ebro. Several outcrops used as sources throughout prehistory have been identified in this area (Tarriño 2001: 14; Tarriño \& Aguirre 1997; Tarriño \& Mujika 2003; Tarriño \& Normand 2002; Tarriño et al. 1989, 1998, 2007b, 2016). These studies have differentiated four geological units, containing 17 different types of siliceous formations (Tarriño et al. 2014).

Of these, the literature including studies on raw materials and flint identification suggested that hunter-gatherers from the Upper Palaeolithic in the Basque region preferred three siliceous formations and their seven varieties rather than other types (Table 1). 
Table 1. Occurrence of main flint types in the area of study.

\begin{tabular}{lll}
\hline $\begin{array}{l}\text { Silicification groups/ } \\
\text { Sedimentary environment }\end{array}$ & Geological age & Variated flint \\
\hline Deep basin flint & Late Cretaceous & $\begin{array}{l}\text { Flysch (Kurtzia, Bidache, } \\
\text { Gaintxurizketa), Salies de Bearn } \\
\text { Cuter marine platform flint }\end{array}$ \\
$\begin{array}{l}\text { Continental Flint } \\
\text { (palustrine-lacustrine) }\end{array}$ & $\begin{array}{l}\text { Palaeogene } \\
\text { Miocene }\end{array}$ & Treviño \\
\hline
\end{tabular}

The geographic distribution of siliceous formations and their respective flint types covers the entire research area, the Basque region, promoting the understanding of mobility and territoriality dynamics of hunter-gatherer communities (Figure 1).

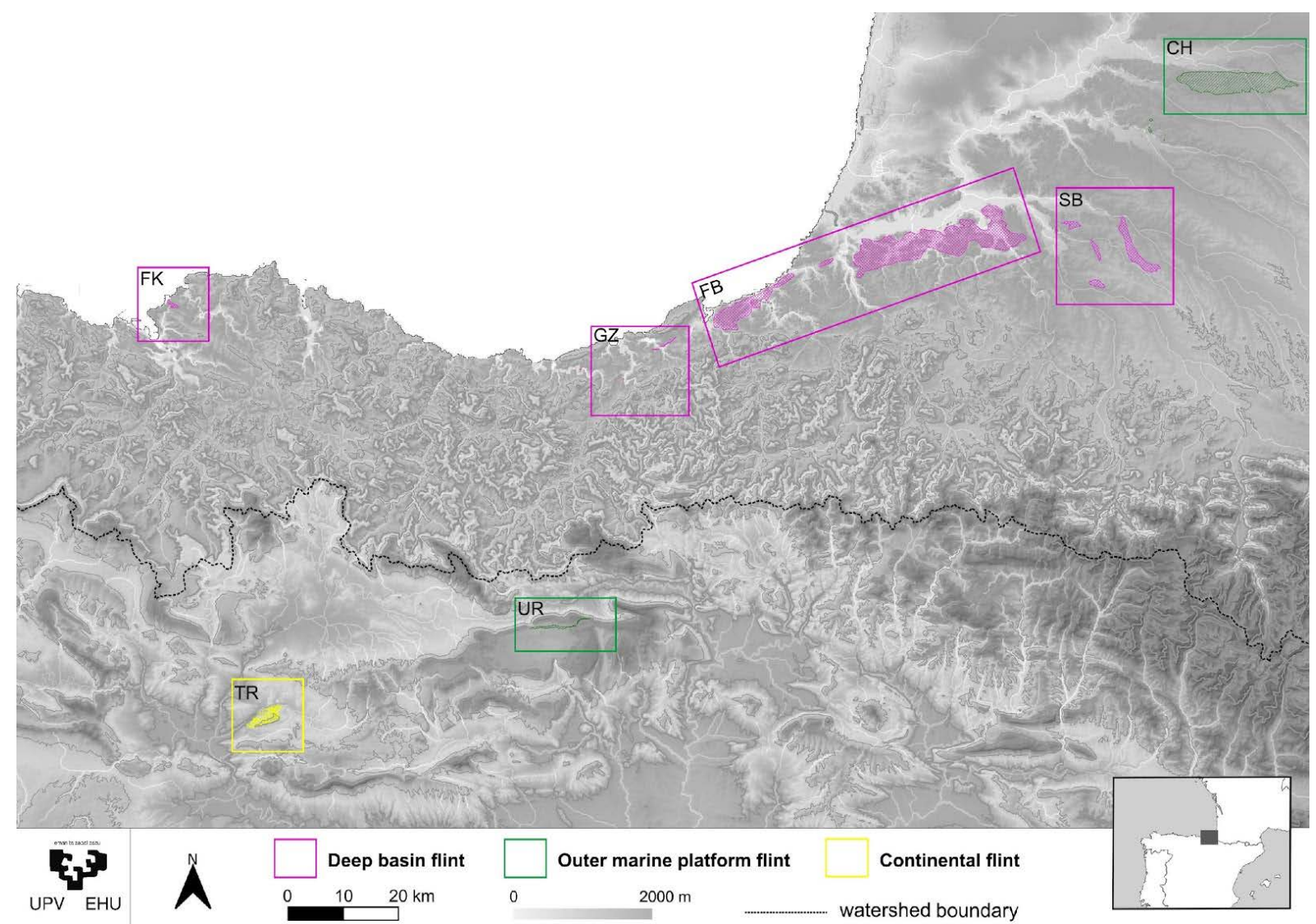

Figure 1. Digital elevation model showing the location of the geological outcrops in the research area. Modified from Sánchez et al. 2016. Type of flint: (FK= Flysch Kurtzia flint, GZ= Flysch Gaintxurizketa flint, FB= Flysch Bidache flint, $\mathrm{SB}=$ Salies de Bearn flint, $\mathrm{CH}=$ Chalosse flint, $\mathrm{UR}=$ Urbasa flint, $\mathrm{TR}=$ Treviño flint)

\section{1. Deep basin flints}

This name is applied to the turbiditic geological formation deposited in deep environments (drop-off of the marine basin). The Late Cretaceous formations belong to the periods between the Cenomanian and the Campanian (Mathey 1987: 328). The bedrock consists of alternating bioclastic calcarenites mainly with fragments of molluscs and sponge spicules. Pelletoids, planktonic foraminifera, detritic quartz and heavy minerals can sometimes be observed. They are usually in the characteristic parallel or undulating laminations characteristic of turbidites. 
The most important appears in Late Cretaceous outcrops to both the north and the south of the Pyrenees. Further outcrops are known in the Palaeocene in the Pyrenees in Navarre. The main Flysch varieties detected in archaeological deposits are:

Kurtzia Flysch flint (FK) (Cenomanian-Santonian, Late Cretaceous). It was described by Tarriño (2001: 69) in the area of Barrika (Biscay). It is found in a bed about $40 \mathrm{~m}$ thick which includes chaotic blocks (olistostrome) in the sandy flysch that the coastline intercepts in the cliffs. Sea erosion releases the flint fragments that are in a marly-clayey matrix so the blocks can easily be gathered. The outer surfaces of the stones usually show the marks of marine abrasion, in the area of the outcrop (in the coastal area between Punta Galea and Plentzia Bay) (Figure 2.1).

1)
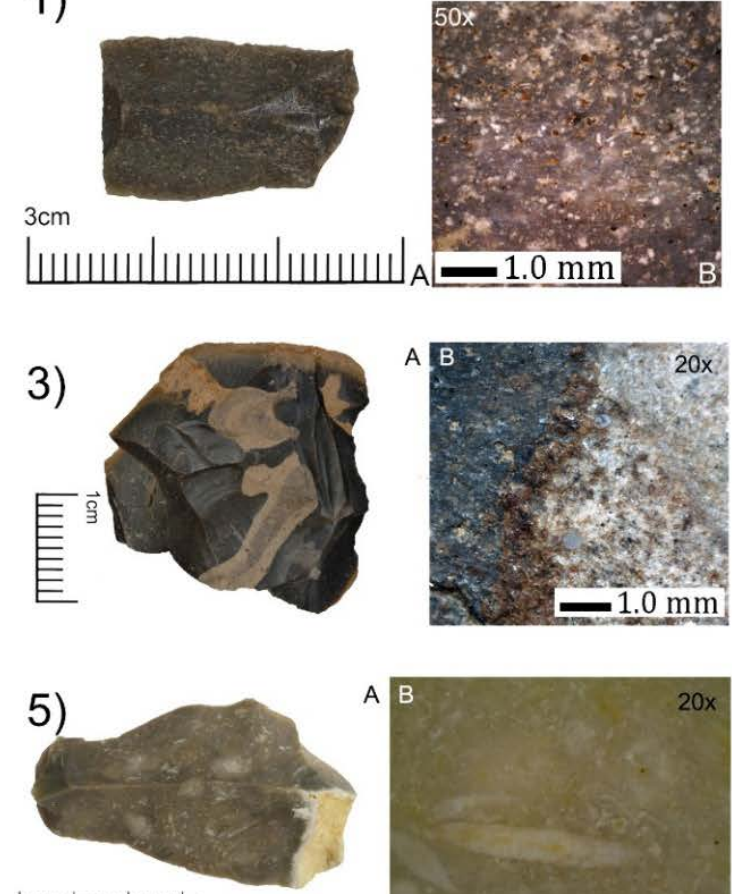

щшшешшшешшш $3 \mathrm{~cm}$
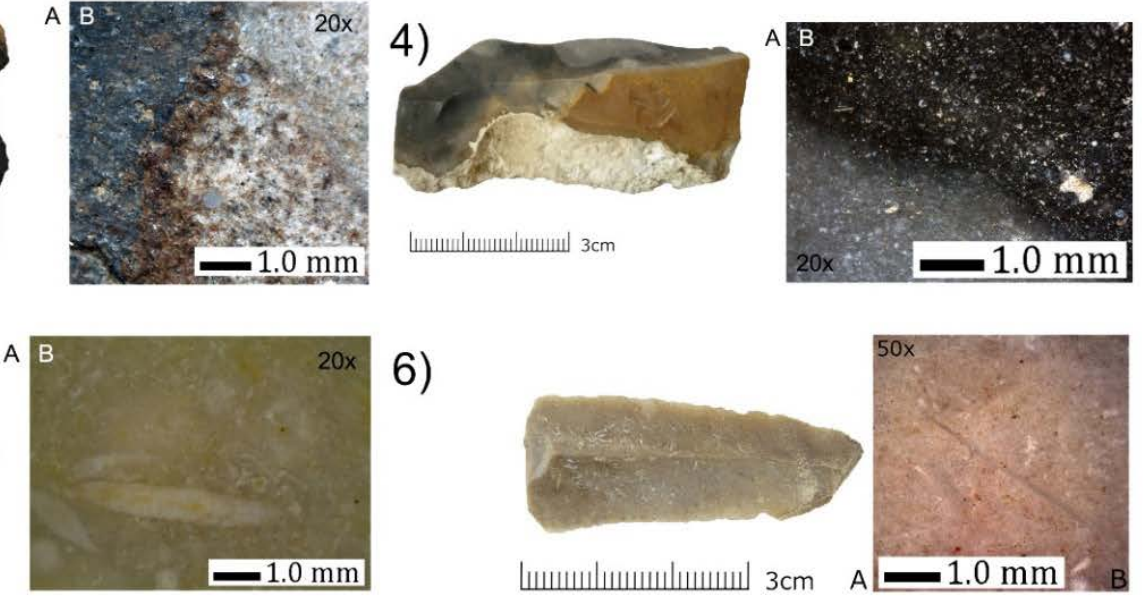

6)
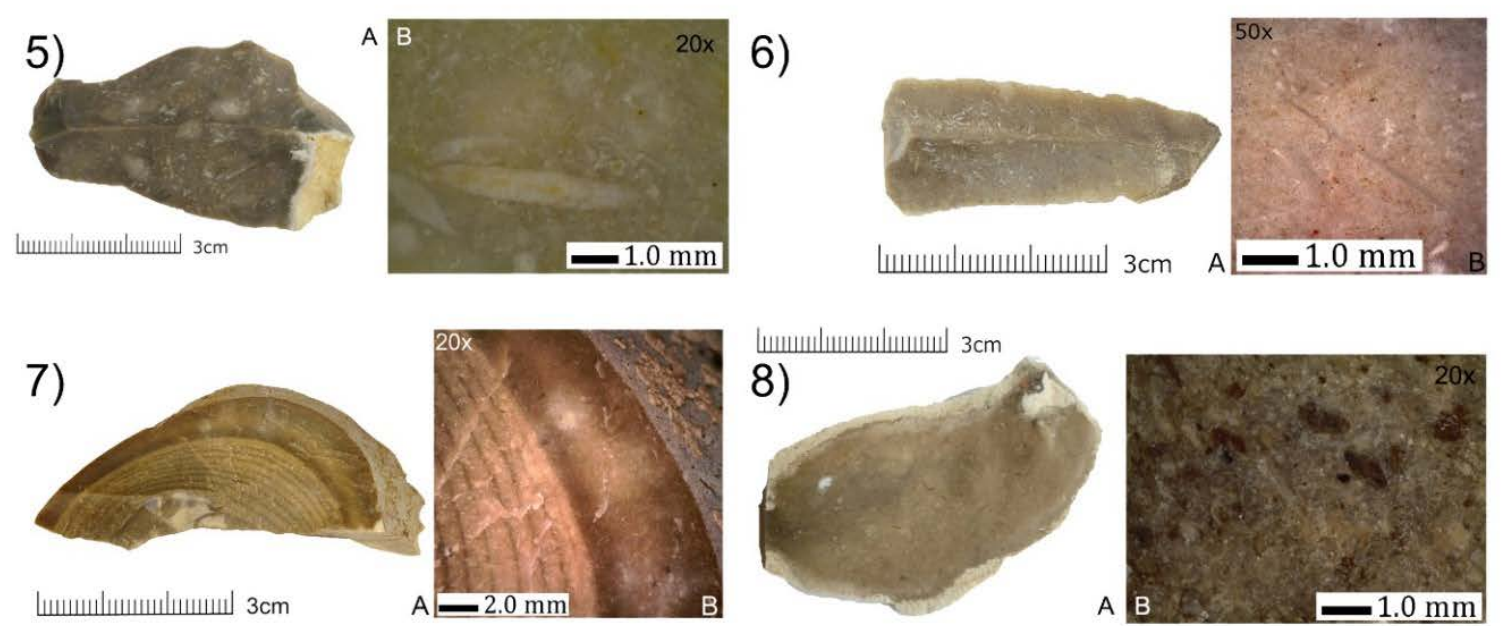

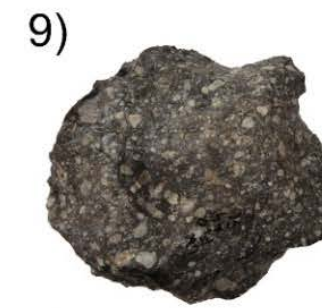

шшلшшшишшши $3 \mathrm{~cm}$
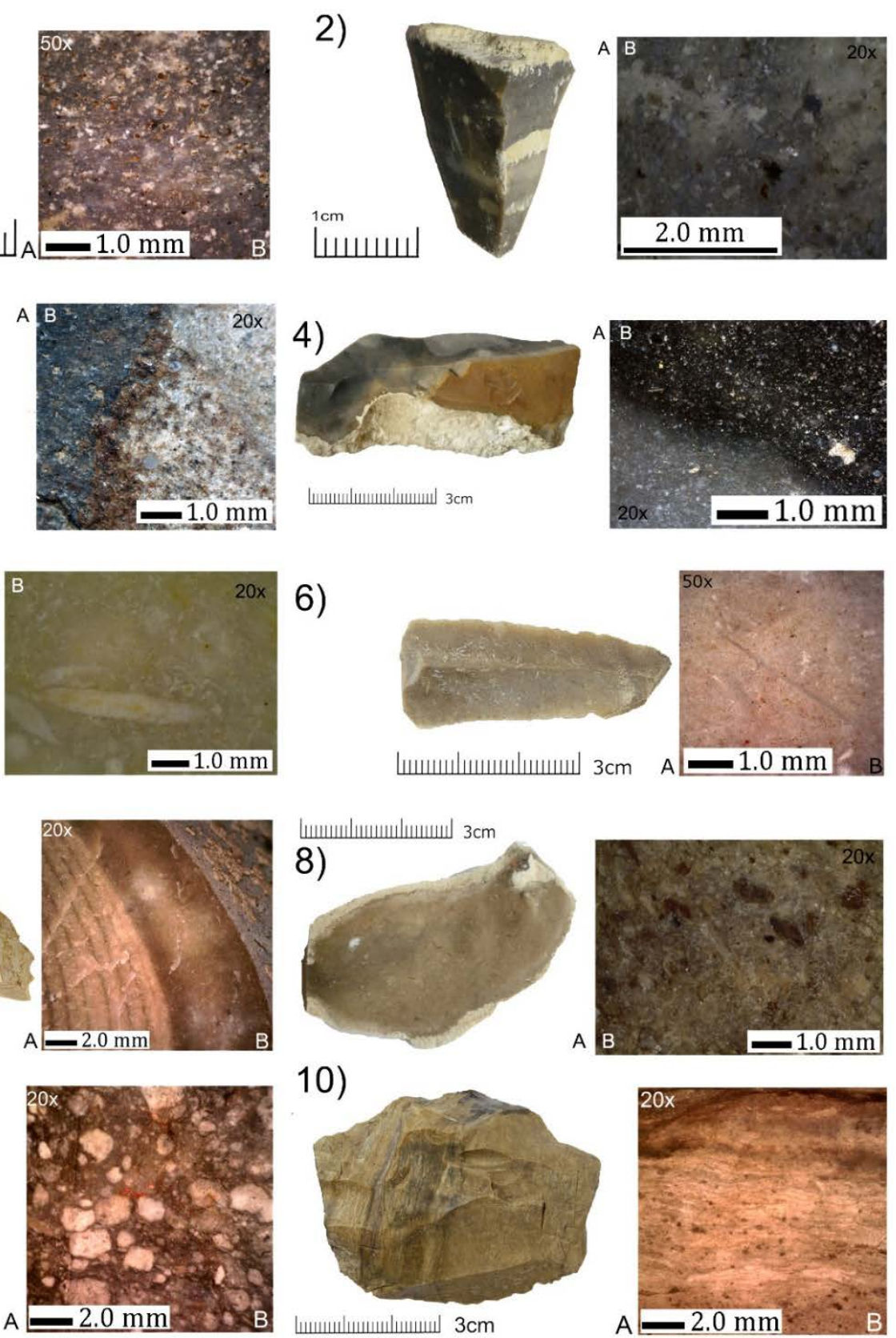

шшшшшшшшшш $3 \mathrm{~cm}$
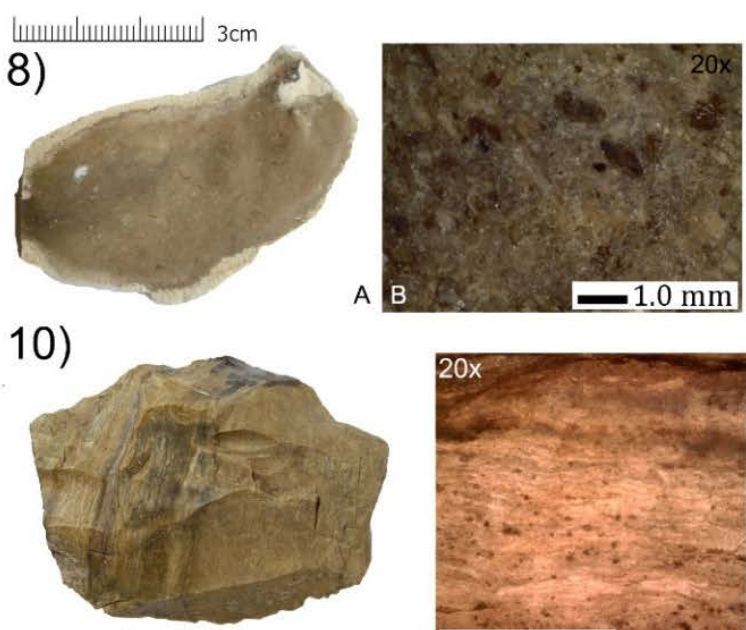

шшшшшшшلшшшل $3 \mathrm{~cm}$

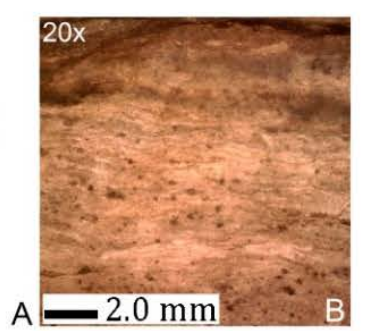

Figure 2. Macroscopic and microscopic pictures of the flints described in this research. Microscopic pictures were taken at 20x or at 50x magnification on most representative surfaces: 1) Kurtzia Flysch flint; 2) Bidache Flysch flint; 3) Gaintxurizketa Flysch flint; 4) Salies de Bearn flint; 5) Chalosse flint; 6) Urbasa flint; 7) Treviño Flint, nodular with bioclasts variety; 8) Treviño flint, silcrete with fenestral porosity; 9) Treviño flint with abundant root traces; 10) Treviño flint with algal lamination. 
Bidache Flysch flint (FB) (Campanian, Late Cretaceous). This is a Flysch flint variety outcropping between the coast (around Biarritz, Pyrénées-Atlantiques, France) and the town of Bidache (Pyrénées-Atlantiques, France). A large outcrop and flint workshop at Mouguerre (on the River Adour, near Bayonne, Pyrénées-Atlantiques, France) was described by Normand (2002). One of its main macroscopic characteristics is that the parallel turbiditic laminations are usually very clear when the flint has a patina. Other important outcrops/workshops in the same formations are known at Senix, Pavillon Royal and Chabiague on the coast, and Côte 151, near Bidache (Tarriño et al. 2007a) (Figure 2.2).

Gaintxurizketa Flysch flint (GZ) (Campanian, Late Cretaceous). Breccial formations (megaturbidites) in the Deba-Irún corridor (Gipuzkoa) near Gaintxurizketa (Irún) also contain large amounts of flint (Arrizabalaga et al. 2014; Tarriño \& Mujika 2003) (Figure 2.3).

Salies de Bearn flint (SB). They appear as irregular nodules with abundant bioturbations rich in carbonate relics, giving them a zoned appearance. It is common to find planktonic foraminifera that shows their depositional environment was a deep marine basin (Normand 2002) (Figure 2.4).

\section{2. Outer marine platform flints}

External marine platform environments are related to marine sedimentation dynamics. In general, the varieties of flint associated with this environment are characterised by its fine-grain texture, with bioclastic inclusions and nodular external morphologies.

Chalosse flint $(\mathrm{CH})$. This bioclastic flint formed in carbonate Late Cretaceous platforms. It crops out in the sector of the Audignon-Montaut anticline and on the edges of the BastennesGaujacq diapir (Landes, France). It is a nodular flint which is usually translucent in blackish to greyish tones. When it has a patina, it becomes white or yellowish, more or less zoned depending on the specimen. It is fine-grained with abundant bioclastic inclusions, especially bryozoa and macroforaminifera (Lepidorbitoides), which are most common in the AudignonMontaut area (Bon et al. 1996; Bon et al. 2002; Foucher 2004; Normand 1986). It is one of the flint varieties in Maastrichtian outcrops (Late Cretaceous) (Chalard et al. 2010; Fernandes 2012: 182; Fernandes et al. 2013; Seronie-Vivien et al. 2006). It is generally found in the alterites covering the gentle depressions at the foot of the small escarpments formed by the limestone containing the flint (Figure 2.5).

Urbasa flint (UR). This variety crops out in the karst of the Sierra de Urbasa (Navarre). It has been dated in the Middle Thanetian (Palaeocene) based on benthic foraminifera: discocyclinids (D. sueunesi) and nummulitids (N. heberti) (Baceta 1996). It formed in the outer marine platform and, in addition to the macroforaminifera, abundant remains of echinoderms and very characteristic incipient microdolomitisation are also frequent (Tarriño et al. 2007b). This variety usually appears in nodules (Tarriño 2001: 85; Tarriño \& Aguirre 1997). The karstification of the carbonated formation containing the flint allowed it to be used in prehistory. Weathering dissolves the limestone, releasing the flint nodules that accumulate in depressions and the bottom of dolines (Knaut 1994), where they could easily be gathered by prehistoric groups (Figure 2.6).

\section{3. Continental flint}

Continental sedimentary environments present a great variety of formations being the Treviño flint associated with lacustrine-palustrine sedimentary processes.

Treviño flint (TR). This flint variety appears in Miocene bedrock (continental Tertiary) in the Miranda-Treviño depression (southern Álava). The best outcrops are in the Sierra de Araico (Treviño-Alava) and its prolongation towards the north in the Cucho-Busto Hills (Treviño). 
This flint formed in lacustrine-palustrine environments included in an eminently carbonated group with compact limestone and dolomite, dolomitic limestone and calcareous dolomite. Fossils from continental environments predominate (gastropods, ostracods, pedotubules, etc.) The most usual silicifications are silcretes (stratiform siliceous layers). Four main siliceous microfacies have been discriminated (Tarriño 2006: 86):

Nodular flint with bioclasts. It usually displays Liesegang rings (Figure 2.7).

Gritty silcrete with fenestral porosity and stratiform structure (Figure 2.8).

Stratiform breccial silcrete with abundant root traces and porosity with vadose cementation (Figure 2.9).

Banded micrite with algal lamination and occasionally ostracods (Figure 2.10).

In this research the location of the geological formations where these flints crop out or the formation where flints are embedded is shown. We are aware Palaeolithic societies could acquire flint in these outcrops and surrounding, but also on secondary deposits where these flints were deposited under different erosive and sedimentary conditions. The analysis of the latter constitutes a new challenge in raw material research in the area (Fernandes et al. 2013)

\section{Changes in Upper Palaeolithic hunter-gatherer territoriality and mobility studies based on raw material researches}

As explained above, the eastern sector of the Cantabrian region is a privileged area for the study of siliceous raw materials, owing to the number of outcrops that were used and the tradition in Palaeolithic research. This has resulted in a theoretical-practical framework as a point of reference for the study of hunter-gatherer mobility and territoriality within that chronocultural setting.

When the procurement of raw materials at the outcrops is linked to studies of the lithic assemblages found in archaeological deposits, we are connecting the two ends of the lithic chaîne opératoire, from acquisition to discard. For an appropriate resolution of these studies, allowing the extraction of archaeological information that can be used for a better understanding of the socioeconomic characteristics of Palaeolithic groups, an epistemological procedure that is still far from complete should be followed. In this sequence, the first step is the petrological characterization of the flint outcrops. The second is a realistic correlation between the available raw materials and those found in the excavated stratigraphy, in quantitative terms.

It can be stated that these first phases are now well on the way to being fulfilled on both sides (peninsular and continental) of the Basque region. However, while they are essential, they are still insufficient at an explanatory level, and therefore alternative ways to interpret the lithic record are currently being explored (Prieto et al. 2016; Ríos-Garaizar \& García 2015). Nearly all of these are based on the evidence that, in addition to their different locations, the specific characteristics of each flint type (not only petrological but also in terms of their format or usual natural size) make them suitable for a particular need. These needs also changed over time, for example as lithic implements reduced in size in the course of the Upper Palaeolithic, more laminar and smaller blanks were required. The location of the resources also needs further considerations, as regards their primary accessibility (depending on the altitude of the outcrop, the geomorphology of the area, etc.) and the more diffuse and harder to determine factor of the visibility of the outcrop at any particular time (for instance, depending on the vegetation density), the ease in removing the flint from the bedrock, and relative abundance of the raw material nodules or tablets. Other factors are more difficult to calibrate from an archaeological perspective, such as control over a valuable resource by one or several groups, in opposition to more distant communities. 
During the last decades on the Basque crossroads, several pieces of research have considered different analytical variables, such as technological, morpho-typological, metric and functional. The definition and identification of raw materials is a further characteristic to be analyzed. In this regard, lithic assemblages at archaeological sites can be understood from these parameters which, in an individual way, provide quantitative data. These datasets are the foundation on which interpretations are based and offer the possibility of synchronic and diachronic comparative studies for a single site or between different sites. The holistic analysis of lithic assemblages aims to appreciate in those collections the social and economic activities of prehistoric communities. Consequently, the most promising avenues of research are oriented towards the territoriality and mobility of the groups, but also on the social relations and economic activities involved in the procurement and management of the lithic resources, enabling their development.

As raw material studies advance and knowledge of Palaeolithic societies increases, together with the appearance of new tools for their study, we should be able to pose new questions and reappraise old concepts, which may have become outdated.

One example is the calculation of the linear distance between the flint outcrop and the site. Researchers' attention was focused on that correspondence in the earliest stages in Palaeolithic mobility studies when the various flint types found in a deposit were being characterized and the geological outcrops were being located. At that time, the calculation of the Euclidian distance or straight-line distance between outcrop and site represented a great step forward for research. However, the study of raw materials is now in another stage. First, in the western Pyrenees, precise petrological characterizations have been made for more of the flint artefacts found in the deposits and the exact location of the source of those materials is known. Second, the increasing use of Geographical Information Systems (GIS) and other digital technologies enable new ways of measuring the distance between two points on the map. This is, therefore, the right moment to reconsider whether the Euclidian distance is the best way to determine the proximity of a site to the outcrops where flint was procured. It should be recalled that this parameter is used to establish whether each flint variety in a given archaeological assemblage is regarded as allochthonous or autochthonous (Figure 3).

Recent studies have ranked the different raw materials and introduced the concepts of tracer and super-tracer flint, for the Urbasa and Treviño types, for example Tarriño et al. 2015. The use of GIS has constituted a further step forwards, by modelling the maps to calculate accessibility to the outcrops based on the detailed orography of the terrain between the source outcrop and the archaeological site. This allows two aspects to be assessed precisely: the distance that a flint type can reach from its source; and the level of accessibility of the outcrops from the sites (Prieto et al. 2016). This approach allows accessibility to be measured with new units, like the 'cost' or 'effort' involved in travelling across the terrain, using the 'Cost Distance' tool in the GIS. The application of these parameters achieves a more realistic appreciation of the real distance between the place where the raw material was acquired and the site where the final product was discarded (Figure 3.A).

Another recent contribution to the adaptation of the straight-line distance as the main measurement of the distance between outcrop and site has been the application of fuzzy logic to estimate the degree to which lithic raw materials are autochthonous or allochthonous (Sánchez et al. 2016). The numerical values obtained by spatial analysis (by Cost Distance Analysis) are compared with the volume of flint found in each archaeological level using descriptive statistics and fuzzy logic (Figure 3.B). Using the three main outcrops that supplied Upper Palaeolithic hunter-gatherers in the peninsular Basque Country (Kurtzia Flysch, Treviño and Urbasa), a map was produced showing the distribution of the flint from each one. As well as determining the direction and most appropriate routes for mobility between the site and its raw material sources, the characterisation of this data with fuzzy logic meant that the 
autochthonous or allochthonous nature of each particular flint type could be defined for a given site rather than an universal factor based on a specific historical hunter-gatherer society (Binford 1982, 2001).
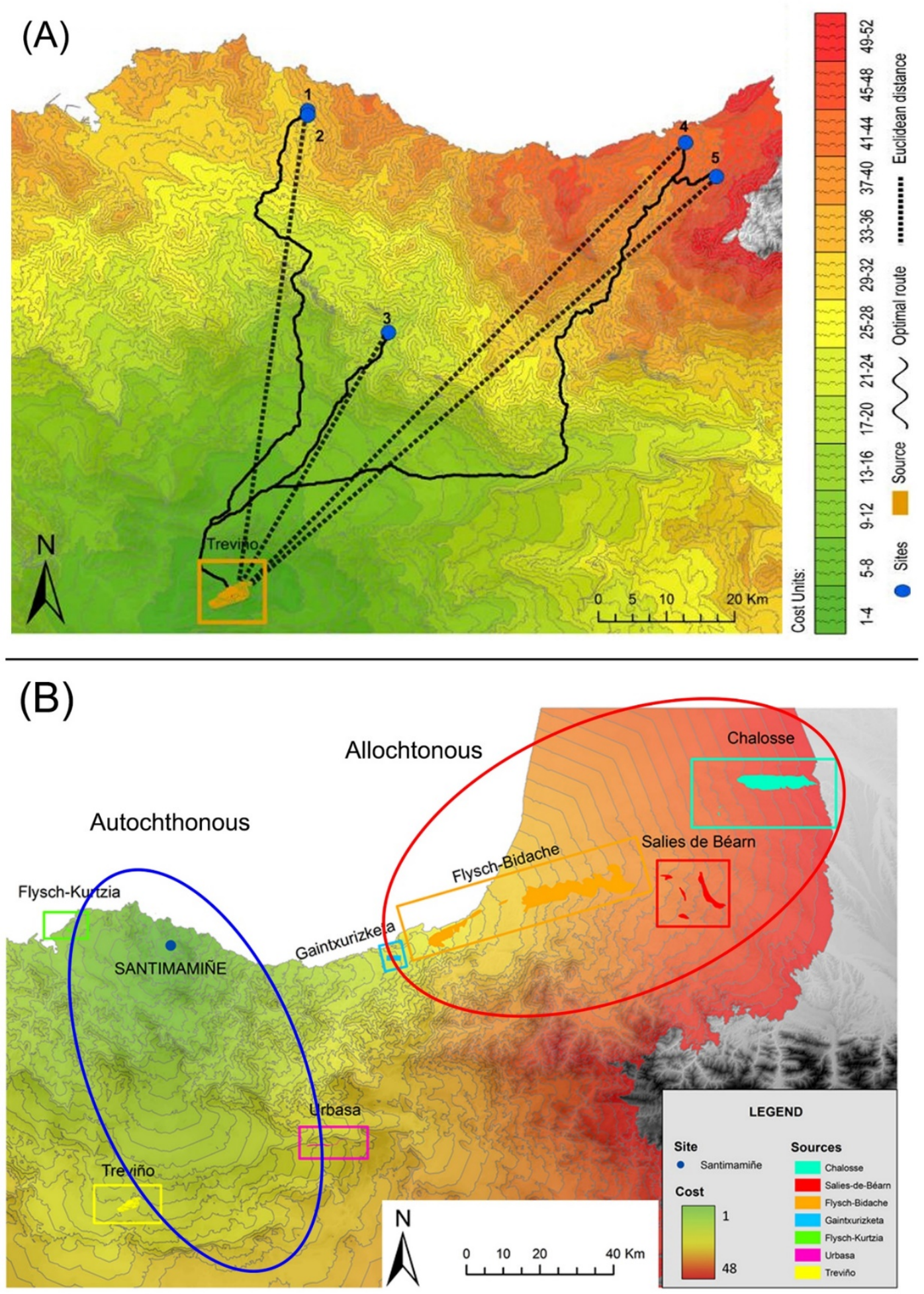

Figure 3. Raw material diffusion/procurement models discussed in this article. A) Map of the expansion of the Treviño flint representing the three types of measurement: euclidean distance, distance through the optimal route and cost. Modified from Prieto et al. 2016. B) Raw material procurement model based on the Cost Units involved to access each flint outcrop from a determined archaeological site. The autochthony and allochthony of each flint type are determined from each archaeological site and based on the accessibility to each catchment area. Modified from Sánchez et al. 2016. 
Finally, with descriptive statistics and the technological and morphomodal structures of Analytical Typology (Figure 4), management patterns can be proposed regarding the outcrops for each stratigraphic unit being studied (García-Rojas et al. 2017). In this way, in addition to determining the siliceous outcrops exploited by the Palaeolithic communities and its accessibility, we are able to understand how they were managed by relating specific flint types or varieties to certain technological products. The latter is also used to analyze the stage of the lithic reduction sequence of each flint type or variety.

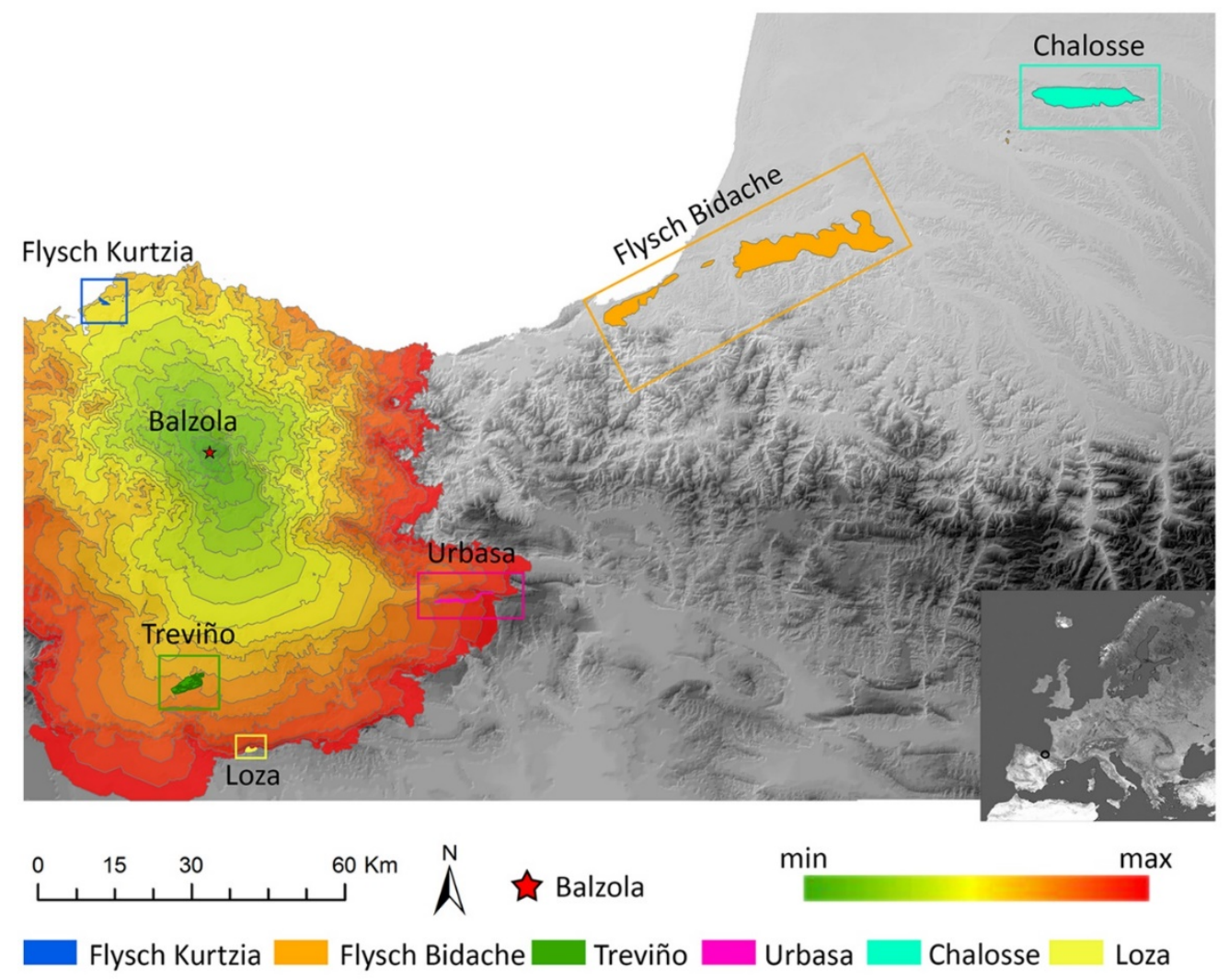

(B)

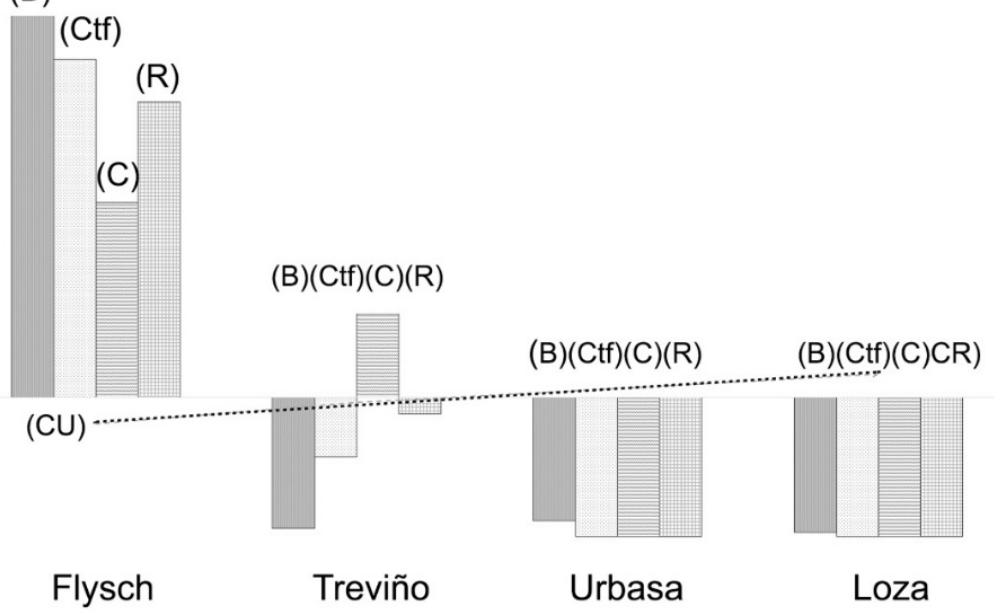

Blanks (B) Core trimming flakes (Ctf) Cores (C) Retouched
products (R) Cost units (CU)

Figure 4. Raw material procurement and management models based on the Cost Units involved to access each flint outcrop and the technical variability analyzed on the lithic assemblage. Modified from García-Rojas et al. 2017. 


\section{Conclusions}

After the intense research of the last three decades, the outcrops of the main flint varieties used in the Palaeolithic have been identified and characterised petrologically. Just a few varieties of evaporitic flint, rarely found in the Palaeolithic record, are still being characterised. Great progress has also been made in the correlation of these resources with Palaeolithic archaeological assemblages and, most important of all, the protocol for the determination of lithic raw materials has become integrated into the methodology employed in the reconstruction of the lithic chaîne opératoire, from procurement to discard.

The current line of research is exploring the relationship between quantitative data and qualitative explanations in order to approach the complex mechanisms of access, procurement and management of raw materials. As a result, based on the determination of the radius of distribution of each flint type from its outcrops, procurement strategies at most sites are hypothesized as belonging to two superimposed models. One of them is based on frequent and recurrent catchment and short-range mobility circuits to obtain autochthonous flint; and the other on sporadic acquisition within larger mobility circuits, seen in the presence of allochthonous flint types. The geographic position of each site marks clear differences between the flint types chosen and, at the same time, areas of influence with the different archaeological sites as their central point. The identification of different steps in the chaîne opératoire in the assemblages provides further information about the use of each outcrop and adds details to the procurement models. It would be possible to make a diachronic interpretation for the whole Upper Palaeolithic.

In addition to these aspects of research, the main issue still remaining is related to the alternative approaches noted in the Discussion. Quantitative data is essential but insufficient for an overall comprehension of the significance of the lithic chaîne opératoire in the socioeconomic framework and historical dynamics of Palaeolithic hunter-gatherers. We need new methodological and epistemological tools to answer more profound questions about qualitative aspects, such as the motives that led those societies to be selective when choosing a particular outcrop for a determinate use, taking into account that the distribution of lithic resources depends on geological patterns that would have been arbitrary in the eyes of the Palaeolithic groups. These lines of research are related with the understanding of catchment areas to understand individual actions carried out when Palaeolithic people laboured and selected raw material on zones where interesting rocks are dispersed on the field or inside a heterogeneous matrix of other stones (Prieto 2018: 553; Prieto et al. 2019, 2020). The characterisation of other raw materials such as quartzites, quartz, lutites or volcanic rocks is also important because its research opens new trends on understanding management and procurement of raw materials (Fernández-Eraso et al. 2017). The increase of studies that research catchment areas by looking for traces of extractives actions, quarrying or mining could also help us to better understand the aforementioned discussion (Tarriño et al. 2014). We imagine that future lithic raw material studies will be along this line.

In sum, advances in methodology allow the proposal of mobility and territoriality models that, while they will not match exactly the systems used by Upper Palaeolithic communities, represent significant progress in understanding the social and economic dynamics of huntergatherer groups. This is enabling an in-depth historical reconstruction of greater resolution.

\section{Acknowledgements}

This research was partially supported by the project HAR2017-82483-C3-1-P financed by the Spanish Ministry of Science and the Consolidated Research Group in Prehistory of the Basque Country University (IT- 1223-19). M. García-Rojas, E. Dominguez-Ballesteros, A. 
Prieto, A. Calvo, A. Sánchez and A. Arrizabalaga are part of this project and they are members of the research group.

E. Dominguez-Ballesteros, A. Prieto and A. Calvo are funded by the Education Department of the Government of the Basque Country through a postdoctoral fellowship (POS_2019_1_0004, POS_2018_1_0021 and POS_2019_1_0017, respectively).

\section{References}

Arrizabalaga, A., Calvo, A., Elorrieta, I., Tapia, J. \& Tarriño, A. 2014, Where to and what for? Mobility Patterns and the Management of Lithic Resources by Gravettian HunterGatherers in the Western Pyrenees. Journal of Anthropological Research, 70: 233-261. doi:10.3998/jar.0521004.0070.204

Arrizabalaga, A. \& Tarriño, A. 2010, Caracterización de los recursos líticos utilizados en el yacimiento paleolítico de Irikaitz (Zestoa, Gipuzkoa). Un nuevo recurso mineral: La vulcanita. In: Minerales y rocas en las sociedades prehistóricas, (Domínguez-Bella, S., Ramos, J., Gutiérrez, J.M. \& Pérez, M., Eds.), Servicio de Publicaciones de la Universidad de Cádiz, Cadiz: p. 91-97. (in Spanish) ("Lithic raw material characterisation of the Palaeolithic site of Irikaitz (Zestoa, Gipuzkoa). A new mineral resource: The vulcanite")

Baceta, J.I. 1996, El Maastrichtiense superior, Paleoceno e Ilerdiense inferior de la Región Vasco-Cantábrica: secuencias deposicionales, facies y evolución paleográfica at the Departamento de Estratigrafía y Paleontología. PhD thesis at the Departamento de Geología, Universidad del País Vasco/Euskal Herriko Universitatea, Bilbao, 372 p. (in Spanish) ("Upper Maastrichtian, Paleocene and Lower Ilerdence from BasqueCantabrian Region: depositional sequences, facies and paleographical evolution")

Binford, L.R. 1982, The archaeology of place. Journal of Anthropological Archaeology, 1(1): 5-31. doi:10.1016/0278-4165(82)90006-X

Binford, L.R. 2001, Constructing Frames of Reference. An Analytical Method for Archaeological Theory Building Using Hunter gatherer and Environmental Data Sets. University of California Press, Berkeley, 583 p.

Bon, F., Chauvaud, D., Dartiguepeyrou, S., Gardère, Ph., \& Mensan R. 1996, La caractérisation du silex de Chalosse. Antiquités nationales, 28: 33-38. (in French) ("The Characterisation of the Chalosse flint")

Bon, F., Chauvaud, D., Dartiguepeyrou, S., Gardère, Ph, Klaric, L., \& Mensan, R. 2002. Les ressources en silex de la Chalosse centrale: gîtes et ateliers du dòme diapir de Bastennes-Gaujacq et de l'anticlinal d'Audignon. In: Comportements techniques et économiques des sociétés du Paléolithique supérieur dans le contexte pyrénéen, (Cazals, N. Ed.), Projet Collectif de Recherche Service Regional de l'Archéologie de Midi-Pyrénées, Toulouse : p. 47-63. (in French) ("The flint resources of the center of Chalosse: accommodation and workshops of the Diapir de Bastennes-Gaujacq and the anticlinal of Audignon,”)

Calvo, A. 2012, El yacimiento gravetiense al aire libre de Ametzagaina (Donostia, País Vasco). Los tecno-complejos líticos del Conjunto Oeste. CKQ: Estudios de Cuaternario/Kuaternario Ikasketak/Quaternary Studies, 2: 15-32. (in Spanish) ("The Gravettian open air site of Ametzagaina (Donostia, Basque Country). The lithic technocomplexes of the Conjunto Oeste") 
Calvo, A. 2019, El Gravetiense en el Pirineo occidental: dinámicas de aprovisionamiento y gestión tecnológica de las materias primas líticas/The Gravettian in the western Pyrenees: dynamics of procurement and technological management of lithic raw materials. PhD thesis at the Departamento de Geografía, Prehistoria y Arqueología, Universidad del País Vasco/Euskal Herriko Unibertsitatea, Vitoria-Gasteiz, 680 p.

Calvo, A., Tapia, J., Arrizabalaga, A., Iriarte-Chiapusso, J.M. 2012, El yacimiento de Ametzagaina (Donostia, País Vasco). Un campamento gravetiense al aire libre en el Cantábrico. In: Pensando el Gravetiense: Nuevos datos para la región cantábrica en su contexto peninsular y pirenáico, (De las Heras, C., Lasheras, J.A., Arrizabalaga, A. \& de la Rasilla, M., Eds.), Monografías del Museo Nacional y Centro de Investigación de Altamira Vol. 23, Ministerio de Educación y Cultura., Madrid: p. 229-240. (in Spanish), ("The archaeological site of Ametzagaina (Donostia, Basque Country). A Gravettian open air campsite in the Cantabrian region”)

Chalard, P., Bon, F., Bruxelles, L., Ducasse, S., Teyssandier, N., Renard, C., Gardere, P., Guillermin, P., Lacombe, S., Langlais, M., Mensan, R., Normand, C., Simonnet, R. \& Tarriño, A. 2010, Chalosse type flint: exploitation and distribution of a lithologic tracer during the Upper Paleolithic, Southern France. In: Ancient mines and quarries: a transAtlantic perspective, (Brewer-LaPorta, M., Burke, A., \& Field, D., Eds), Oxbow Books, Oxford, p 13-22.

Demars, P.Y. 1982, L'utilisation du silex au Paléolithique supérieur: choix, approvisionnement, circulation. L'exemple du bassin de Brive. Vol. 5. Cahiers du Quaternarie. CNRS, París, 253 p. (in French) ("The use of flint in the Upper Palaeolithic: Selection, catchment and circulation. The example of Brive valley")

Doggett S., Kramer K, Straus L. G. 1995, La signification des matières premières lithiques. In: Les derniers chasseurs de rennes du monde pyrénéen. L'abri Dufaure: un gisement tardiglaciaire en Gascogne (fouilles 1980-1984), (Straus L. G. Ed.), Mémoires de la Société Préhistorique Française XXII, Eastham: p. 127-134. (in French) (“The identification of lithic raw materials”)

Elorrieta, I. 2010, El aprovechamiento y disponibilidad de las materias primas silíceas durante el Paleolítico Superior en el Pirineo occidental: El caso de Alkerdi como paradigma. Unpublished, Trabajo para la obtención del Diploma de Estudios Avanzados, Universidad del País Vasco-Euskal/Herriko Unibertsitatea, Vitoria. 206 p. (UPV-EHU), (in Spanish) ("Development and availability of siliceous raw materials during the Upper Palaeolithic in the Western Pyrenees: The case of Alkerdi”)

Elorrieta, I. 2015a, Los efectos retocados del nivel c4d1j de Isturitz: estudio arqueopetrológico desde la Tipología Analítica. In: Seis décadas de tipología analítica: actas en homenaje a Georges Laplace (Calvo, A., Sánchez, A., García-Rojas, M. \& Alonso, M. Eds), Universidad del País Vasco/ Euskal Herriko Unibertsitatea, Vitoria: 156-167 p. (in Spanish) (“The retouched tools of Isturitz's c4d1j level: archaeological study from Analytical Typology”)

Elorrieta, I. 2015b, Aprovisionamiento y disponibilidad de las materias primas silíceas en el Pirineo Occidental durante el Paleolítico superior. $\mathrm{PhD}$ thesis at the Departamento de Geografía, Prehistoria y Arqueología, Universidad del País Vasco/Euskal Herriko Unibertsitatea, Vitoria-Gasteiz, 459 p. (in Spanish) (“Development and availability of silica raw materials in the Western Pyrenees during the Upper Paleolithic”) 
Elorrieta, I., Tarriño, A. 2016, La gestión de las materias primas silíceas en el Pirineo Occidental: la ocupación Magdaleniense de Berroberria (Urdax, Navarra). Munibe, 67: 285-293. (in Spanish) ("Siliceous raw material management in Western Pyrenees: Magdalenian occupation of Berroberria (Navarre, Spain)”). doi:10.21630/maa.2016.67.mis05

Fernandes, P. 2012, Itinéraires et transformations du silex: une pétroarchéologie refondée, application au Paléolithique moyen. PhD thesis at Université de Bordeaux I., Bordeaux, 623 p. (in French) ("Flint routes and transformations: a re-founded petroarchy, application to the Middle Paleolithic")

Fernandes, P., Raynal, J.-P., Tallet, P., Tuffery, C., Piboule, M., Séronie-Vivien, M., SeronieVivien, M.-R., Turq, A., Morala, A., Affolter, J., Millet, D., Millet, F., Bazile, F., Schmidt, P., Foucher, P., Delvigne, V., Liagre, J., Gaillot, S., Morin, A., \& LeandriBressy, C. 2013, Une carte et une base de données pour les formations à silex du sud de la France: un outil pour la pétroarchéologie. PALEO Revue d'archéologie préhistorique, 24: 219-228. (in French) ("A map and a database for flint bearing formations in Southern France: a tool for Petroarchaeology”) doi:10.4000/paleo.2633

Fernández Eraso, J., García Rojas, M., Larreina, D., \& Alonso, M. 2012, Las industrias líticas de Echabarri en el embalse de Urrúnaga (Álava). Kobie Paleantropología, 31: 73-104. (in Spanish) ("The lithic industries of Echabarri, Urrunaga reservoir (Alava)”)

Fernández-Eraso, J., García-Rojas, M., Sánchez, A., Prieto, A., Calvo, A., DomínguezBallesteros, E., Tarriño, A., López-de-Ocáriz, J., Bradtmöller, M. \& Urigoitia, T. 2017, El tecno-complejo del Embalse de Urrúnaga (Álava). Nuevas aportaciones al conocimiento de las sociedades del Paleolítico inferior en el norte de la Península Ibérica. Munibe, 68: 5-31. (in Spanish) (“The techno-complex of Urrúnaga Dam (Álava). New contribution to the knowledge of Lower Palaeolithic societies in the northern Iberian Peninsula”) doi:10.21630/maa.2017.68.04

Fernández Eraso, J., Larreina, D., \& Tarriño, A. 2004, El conjunto lítico de superficie de Itsetsasi en el embalse de Urrúnaga (Álava). Estudios de Arqueología Alavesa, 21: 1766. (in Spanish) ("The lithic industries of Itsesatsi, Urrunaga reservoir (Alava)")

Fernández Eraso, J., Larreina, D., \& Tarriño, A. 2005, El conjunto lítico de Tribitu en el embalse de Urrúnaga (Álava). Estudios de Arqueología Alavesa, 22: 69-122. (in Spanish) ("The lithic industries of Tribitu, Urrunaga reservoir (Alava)")

Foucher, P. 2004, Les industries lithiques du complexe Gravettien-Solutréen dans les Pyrénées: Techno-typologie et circulation des matières siliceuses de part et d'autre de l'axe Pyrénées-Cantabres. PhD thesis at Université de Toulouse 2-le Mirail, Toulouse, 647 p. (in French) ("The lithic industries of the Gravettian-Solutrean complex in the Pyrenees. Techno-typology and circulation of raw materials on both sides of the Pyrenean-Cantabrian Mountains”)

Foucher, P. 2015, Flint economy in the Pyrenees: A general view of siliceous raw material sources and their use in the Pyrenean Gravettian. Journal of Lithic Studies, 2(1): 111129. doi:10.2218/jls.v2il.1306

Geneste, J.M. 1985, Analyse lithique d'idustries mostériennes di Périgord: une aproche technologique du comportement des groupes humains au Paléolithique moyen (2 tomes). PhD thesis at Université de Bourdeux I, Bourdeux, 571 p. (in French) ("Lithic analysis of industries Mousterian in Périgord: a technological approach to the behaviour of human groups in the Middle Paleolithic”) 
Geneste, J.M. 1988, Les industries de la grotte Vaufrey: Technologie du débitage, économie et circulation de la matière première. In: La Grotte Vaufrey à Cènac et Saint-Julien (Dordogne): Paléoenvironnements, Chronologie et Activités Humaines, Vol. 19 (Rigaud, J.P., Ed.) Mémories de la Société Préhistorique Française, Paris: 441-518 (in French) ("The industries of Vaufrey cave: technology, economy and raw material circulation”)

Geneste, J.M., \& Rigaud, J.-Ph. 1989, Matières premiéres lithiques et occupations de l'espace. In Variations des paléomilieux et peuplement préhistorique. In : INQUA: Colloque du comité français de l'Union internationale pour l'étude du quaternaire. Variations des paléo-milieux et peuplement préhistorique, Vol. 13 (Laville, H., Ed.), Cahiers du Quaternaire, CNRS, Bordeaux: p. 205-218. (in French) ("Raw materials and occupations of space. In Palaeoenvironment Variations and Prehistoric Settlement”)

García-Rojas, M. 2014, Dinámicas de talla y gestión de las materias primas silíceas a finales del Pleistoceno en el País Vasco. PhD thesis at the Departamento de Geografía, Prehistoria y Arqueología, Universidad del País Vasco/Euskal Herriko Unibertsitatea, Vitoria-Gasteiz, 558 p. (in Spanish) ("Knapping processes and management of siliceous raw material at the end of the Pleistocene in the Basque Country")

García-Rojas, M., Prieto, A., Sánchez, A., Camarero, C. \& Zapata, L. 2017, The Application of GIS to flint management studies during the Pleistocene to Holocene transition: the case of Baltzola (Dima, Bizkaia, Spain). In: Archaeology and Geomatics. Harvesting the benefits of 10 years of training in the Iberian Peninsula (2006-2015), (Mayoral Herrera, V., Parcero-Oubiña, C. \& Fábrega-Álvarez, P., Eds.), Sidestone Press, Leiden: p. 133-148.

Knauth, L.P. 1994, Petrogenesis of chert. In: Silica. Physical behavior, Geochemistry and materials applications, Vol. 29. (P.J. Heaney, C.T. Prewitt \& G.V. Gibbs, Eds.). Reviews in Mineralogy and Geochemistry, USA: 232-258.

Mathey, B. 1987, Les flyschs Crétacé Supérieur des Pyrénées Basques. Mémoires Géologiques, 12, Université de Dijon: 399 p. (in French) ("The Cretaceous Superior flyschs of the Basque Pyrenees”)

Morala, A. 1984, Perigordien et Aurignacien en Hautes-Agenais. Etude d'assemblages lithiques. À propos des matières premières lithiques. Bulletin de la Société Préhistorique Française, 80(6): 169 p. (in French) ("About lithic raw material in HautAgenais")

Normand, C. 1986, Inventaire des gîtes de matières premières de la Chalosse. In: Recherches de Préhistoire dans les Landes, (Arambourou, R.L., Straus, L. \& Normand, C., Eds.), Bulletin de la Société de Borda. Dax: p. 121-140. (in French) ("Inventory of deposits of raw material in Chalosse")

Normand, C. 1987, Le gisement paléolithique de plein air du Vignès à Tercis (Landes). Bulletin de la Société d'Anthropologie du Sud-Ouest, 22(2), 71-80. (in French) ("The Open Palaeolithic deposit of Vignès in Tercis (Landes)")

Normand, C. 1993, Un atelier de taille de pièces à dos à Tercis (Landes). Archéologie des Pyrénées occidentales et des Landes, 1992/1993, 12: 27-51, (in French) (“A workshop for backed tools in Tercis (Landes)”)

Normand, C. 2002, Les ressources en matières premières siliceuses dans la basse vallée de l'Adour et de ses affluents, In: Comportements techniques et économiques des sociétés 
du Paléolithique supérieur dans le contexte pyrénéen, (Cazals, N. Ed.), Projet Collectif de Recherche Service Regional de l'Archéologie de Midi-Pyrénées, Toulouse : p. 26-46. (in French) ("Siliceous raw material resources in the lower Adour valley and its tributaries”, Comportements techniques et économiques des sociétés du Paléolithique supérieur dans le contexte pyrénéen”)

Ortiz, L., Vivanco, L., Ferreira, J.J., Lobo, P.J., Muñoz, M.D., Pinillos, R., Tarriño, J.M. \& Tarriño, A. 1990, El hábitat en la prehistoria del valle del Río Rojo (Álava). Cuadernos de Sección de Eusko-Ikaskuntza (Prehistoria-Arqueología), 3: 1-315. (in Spanish) ("The habitat in the Prehistory of the Rojo River Valley (Álava)")

Prieto, A. 2018, Procurement and management of quartzite in the Cantabrian Region: The Middle and Upper Palaeolithic in the Deva, Cares and Güeña Valleys. PhD thesis at the Departamento de Geografía, Prehistoria y Arqueología, Universidad del País Vasco/Euskal Herriko Unibertsitatea, Vitoria-Gasteiz, 589 p.

Prieto, A., García-Rojas, M., Sánchez, A., Calvo, A., Domínguez-Ballesteros, E., Ordoño, J. \& García Collado, M.I. 2016, Stones in Motion: Cost units to understand flint procurement strategies during the Upper Palaeolithic in the south-western Pyrenees using GIS. Journal of Lithic Studies, 3: 133-160. doi:10.2218/jls.v3i1.1310

Prieto, A., Yusta, I. \& Arrizabalaga, A. 2019, Defining and Characterizing Archaeological Quartzite: Sedimentary and Metamorphic Processes in the Lithic Assemblages of El Habario and El Arteu (Cantabrian Mountains, Northern Spain). Archaeometry, 61(1): 14-30. doi:10.1111/arcm.12397

Prieto, A., Yusta, I. \& Arrizabalaga, A. 2020, From petrographic analysis to stereomicroscopic characterisation: a geoarchaeological approach to identify quartzite artefacts in the Cantabrian Region. Archaeological and Anthropological Sciences, 12(1): 32. doi:10.1007/s12520-019-00981-7

Rios-Garaizar, J. 2013, Industria lítica de los niveles del Paleolítico medio antiguo y Paleolítico superior de la Cueva de Arlanpe (Lemoa, Bizkaia). Kobie, BAI 3: 177-253. (in Spanish) ("Early Middle Palaeolithic and Upper Palaeolithic assemblages from Arlanpe cave (Lemoa, Biscay)")

Rios-Garaizar, J. 2016, Early Middle Palaeolithic occupations at Ventalaperra cave (Cantabrian Region, Northern Iberian Peninsula). Journal of Lithic Studies, 3(1) 161183. doi:10.2218/jls.v3i1.1287

Rios-Garaizar, J., García, A. 2015, Middle Paleolithic Mobility Patterns and Settlement System Variability in the Eastern Cantabrian Region (Iberian Peninsula): A GIS-Based Resource Patching Model. In: Settlement Dynamics of the Middle Palaeolithic and Middle Stone Age, (Conard, N. \& Delanges, A., Eds.), Tübingen Publications in Prehistory, Tubingen: p. 329-360.

Rios-Garaizar, J., Libano, I., Garate, D. 2012, El yacimiento chatelperroniense al aire libre de Aranbaltza (Barrika, Euskadi). Munibe, 63: 81-92. (in Spanish) (“The open air Chatelperronian site of Aranbaltza (Barrika, Basque Country”)

Sánchez, A., Domínguez-Ballesteros, E., García-Rojas, M., Prieto, A., Calvo, A. \& Ordoño, J. 2016, Patrones de aprovisionamiento de sílex de las comunidades superopaleolíticas del Pirineo occidental: el "coste” como medida de análisis a partir de los SIG. Munibe, 67: 235-252. (in Spanish) ("Flint procurement patterns of Upper Paleolithic communities of 
the western Pyrenees: "cost” as a measure of analysis using GIS") doi:10.21630/maa.2016.67.mis02

Sarabia, P. 1999, Notas sobre los modelos de aprovisionamiento de materias primas líticas en el Paleolítico superior de Cueva Morín. Sautuola: Revista del Instituto de Prehistoria y Arqueología, 6: 145-154. (in Spanish) ("Notes about raw material procurement in the Upper Palaeolithic at Cueva Morín")

Séronie-Vivien, M. \& Séronie-Vivien, M.R. 1987, Les silex du Mésozoïque nord-aquitain : approche géologique de l'étude des silex pour servir à la recherche préhistorique. Supplément t. 15 du Bulletin de la Société Linnéenne de Bordeaux. Société Linnéenne de Bordeaux, Bordeaux: 135 p. (in French) ("Flints of the North-Aquitaine Mesozoic: a geological approach to the study of flint for use in prehistoric research")

Séronie-Vivien, M., Séronie-Vivien, M.-R., \& Foucher, P. 2006, L'économie du silex au Paléolithique supérieur dans le bassin d'Aquitaine. Le cas des silex à lépidorbitoïdes des Pyrénées centrales. Caractérisation et implications méthodologiques. PALEO Revue d'archéologie préhistorique, 18: 193-216. (in French) ("The economy of flint in the Upper Paleolithic in the Aquitaine basin. The case of the lepidorbitoid flints of the central Pyrenees. Characterization and methodological implications”) doi:10.4000/paleo.316

Simonet, A. 2010, Typologie des armatures lithiques gravettiennes de la grotte d'Isturitz (Pyrénées-Atlantiques, France). Archaeopress BAR International Series 2156, Oxford, 131 p. (in French) ("Typology of the gravettian lithic armatures from Isturitz cave (Pyrénées-Atlantiques, France)”)

Simonnet, R. 1981, Carte des gîtes à silex des Pré-Pyrénées. In: La Préhistoire en Quercy dans le contexte de Midi-Pyrénées, Congrès Préhistorique de France, MontaubanCahors 1979, Société Préhistorique Française, p. 308-323. (in French) ("Map of flint deposits from the Pre-Pyrenees")

Soto, A. 2014, Producción y gestión de la industria lítica de Atxoste (Álava): una aproximación a las sociedades epipaleolíticas y mesolíticas del alto Ebro. $\mathrm{PhD}$ thesis at the Departamento de Geografía, Prehistoria y Arqueología, Universidad del País Vasco/Euskal Herriko Unibertsitatea, Vitoria-Gasteiz, 1000 p. (in Spanish) ("Production and management of the Atxoste lithic industry (Álava): an approach to the epipaleolithic and mesolithic societies of the upper Ebro")

Straus, L., Clark, G., Ordaz, J., Suárez, L. \& Esbert, R. 1986, Patterns of lithic raw material variation at La Riera. In: La Riera Cave, Stone age hunter-gatherer adaptations in Northern Spain Vol. 36 (Straus, L. \& Clark, G., Eds.), Arizona State University, Arizona: p. 189-208.

Tarriño, A. 1997, Análisis de restos líticos silíceos del yacimiento arqueológico de Urratxa III (Orozco, Bizkaia). In: El yacimiento de la cueva de Urratxa III (Orozko, Bizkaia) (Margarita Muñoz-Salvatierra, M., Berganza-Gochi, E., Eds), Universidad de Deusto, Deusto, 272 p. (in Spanish) (“Analysis of siliceous lithic remains of the archaeological site of Urratxa III (Orozco, Bizkaia)”)

Tarriño, A. 2000, Estudio de la procedencia de los sílex recuperados en el yacimiento de Labeko Koba (Arrasate, País Vasco). In: Labeko Koba (País Vasco): Hienas y Humanos en los albores del Paleolítico superior, Vol. 52 (Arrizabalaga, Á. \& Altuna, J., Eds.), Munibe, 52, San Sebastián: p. 345-354. (in Spanish) ("Provenance analysis of the chert from the site of Labeko Koba (Arrasate, Basque Country)") 
Tarriño, A. 2001, El sílex en la cuenca vasco cantábrica y pirineo navarro: caracterización y su aprovechamiento en la Prehistoria. PhD thesis at the Departamento de Geografía, Prehistoria y Arqueología, Universidad del País Vasco/Euskal Herriko Unibertsitatea, Vitoria-Gasteiz, 365 p. (in Spanish) ("The Flint in the Basque-Cantabrian Basin and the Navarre Pyrenees: characterization and exploitation in Prehistory”)

Tarriño, A. 2002, Procedencia de los sílex de la industria lítica del yacimiento de Aizpea (Arive, Navarra) In: Cazadores-recolectores en el Pirineo navarro: sitio de Aizpea entre 8000 y 6000 años antes de ahora, (Cava, A., \& Barandiarán, I., Eds), Universidad del País Vasco, Vitoria: p. 51-62 (in Spanish) ("Origin of flint of the lithic industry of the Aizpea site (Arive, Navarra)")

Tarriño, A. 2006, El sílex en la cuenca vasco-cantábrica y Pirineo navarro: caracterización y su aprovechamiento en la Prehistoria. Monografías del Museo Nacional y Centro de Investigación de Altamira, Vol. 21. Ministerio de Educación y Cultura, Madrid, 264 p. (in Spanish) ("Flint in the Basque-Cantabrian basin and the Pyrenees Navarro: characterization and its use in prehistory")

Tarriño, A. 2008, Procedencia de los sílex. In: Cazadores y tallistas en el abrigo de Portugain: una ocupación de Urbasa durante el Tardiglaciar (Cava, A., \& Barandiarán, I., Eds), Fundacion José Miguel de Barandiaran, Vitoria: p 51-62 (in Spanish) ("Hunters and knappers in the Portugain rockshelter: an occupation of Urbasa during the Tardiglacial”)

Tarriño, A. 2011a, Procedencia de los sílex de la industria lítica del yacimiento en cueva de Santimamiñe. In: La cueva de Santimamiñe: Revisión y actualización (2004-2006), (López Quintana, J.C., Ed.), Diputación Foral de Bizkaia, Bilbao: p. 281-290. (in Spanish) ("Provenance of flint from Santimamiñe cave (Kortezubi, Bizkaia)")

Tarriño, A. 2011b, Procedencia de los sílex de la cueva de Aitzbitarte-III (Rentería, Gipuzkoa). In: Ocupaciones humanas en Aitzbitarte III (País Vasco) 33.600-18.400 BP, Vol. 5 (Altuna, J., Mariezkurrena, K. \& Ríos, J., Eds.), EKOB Euskal Kultura Ondare Bilduma, Vitoria-Gasteiz: 353-373. (in Spanish) ("Provenance of flint from AitzbitarteIII Cave (Rentería, Gipuzkoa)")

Tarriño, A., 2017, Procedencia de los sílex recuperados en Praileaitz I (Deba, Gipuzkoa). In: La Cueva de Praileaitz I (Deba, Gipuzkoa, Euskal Herria): intervención arqueológica 2000-2009, (Peñalver, X., San Jose, S., Mujica, J.A. Eds), Munibe Monographs: Anthropology and Archaeology Series, San Sebastián: p. 391-398. (In Spanish) (“Origin of the flint recovered in Praileaitz I (Deba, Gipuzkoa)”)

Tarriño, A. \& Aguirre, M. 1997, Datos preliminares sobre fuentes de aprovisionamiento de rocas silíceas en algunos yacimientos paleolíticos y postpaleolíticos del sector oriental de la cuenca vasco-cantábrica. Veleia, 14: 101-116. (in Spanish) ("Preliminary data of procurement of siliceous rock in some Palaeolithic and Post-Palaeolithic sites at the East of the Basque-Cantabrian basin")

Tarriño, A., Arriortua, I., Elorza, J. 1989, Estudio geológico del área de Peñacerrada (Álava): Petrografía y cristalografía de las silicificaciones existentes. Cuadernos de Sección de Ciencias Naturales, 5: 43-135. (in Spanish) ("Geological study of the area of Peñacerrada (Alava): Petrography and crystallography of existing silicifications”)

Tarriño, A., Bon, F. \& Normand, C. 2007a, Disponibilidad del Sílex como materia prima en la Prehistoria del Pirineo occidental. In: Frontières culturelles dans les Pyrénées préhistoriques, (Cazals, N., González Urquijo, J. \& Terradas, X., Eds.), PubliCan- 
Ediciones de la Universidad de Cantabria, Cantabria: p. 103-123. (in Spanish) ("The availability of flint as raw material in the western Pyrenees Prehistory")

Tarriño, A., Elorrieta, I., García-Rojas, M. \& Sánchez, A. 2014, Neolithic flint mines of Treviño (Basque-Cantabrian Basin, Western Pyrenees, Spain). Journal of Lithic Studies, 1(2): 129-147. doi:10.2218/jls.v1i2.1098

Tarriño, A., Elorrieta, I. \& García-Rojas, M. 2015, Flint as raw material in prehistoric times: Cantabrian Mountain and Western Pyrenees data. Quaternary International, 364: 94108. doi:10.1016/j.quaint.2014.10.061

Tarriño, A., Muñoz-Fernández, E., Elorrieta, I., Normand, C., Rasines, P., García-Rojas, M., \& Pérez-Bartolomé, M. 2016, El sílex en la Cuenca Vasco-Cantábrica y Pirineo occidental: Materia Prima lítica en la Prehistoria. Arqueología de la Arquitectura, 26: 191-228. (in Spanish) ("Flint in the Basque-Cantabrian Basin and the Western Pyrenees: Lithic Raw Material in Prehistory”)

Tarriño, A. \& Mujica, J.A. 2003, Zonas con rocas o minerales aprovechables por el hombre prehistórico. Gaintxurizketa (Irún). Arkeoikuska, 2003: 161-162 (in Spanish) ("Mineral resources and stones potentially used by human populations. Gaintxurizketa (Irún)”)

Tarriño, A., \& Normand, C. 2002, Procedencia de los restos líticos en el Auriñaciense antiguo (C4B1) de Isturiz (Pyrénées-Atlantiques, Francia). Espacio, tiempo y forma. Serie I, Prehistoria y arqueología, pp135-144. (in Spanish) ("Origin of the lithic remains in the Ancient Auriñaciense (C4B1) of Isturiz (Pyrénées-Atlantiques, France)”)

Tarriño, A., Olivares, M., Etxebarria, N., Baceta, J. I., Larrasoaña, J., Yusta, I., Pizarro, J., Cava, A., Barandiarán, I., \& Murelaga, X. 2007b, El sílex de tipo "Urbasa": Caracterización petrológica y geoquímica de un marcador litológico en yacimientos arqueológicos del Suroeste europeo durante el Pleistoceno superior y Holoceno inicial. Geogaceta, 43: 127-130. (in Spanish) (“The "Urbasa” type flint. Main petrological and geochemical features of a litologhic marker in late Pleistocene and earliest Holocene archaeological sites”)

Tarriño, A., Yusta, I. \& Aguirre, M. 1998, Indicios de circulación a larga distancia de sílex en el Pleistoceno superior. Datos petrográficos y geoquímicos de materiales arqueológicos de Antoliñako Koba. Boletín de la Sociedad Española de Mineralogía, 21-A: 200-201. (in Spanish) ("Long distance flint tracks at the Upper Palaeolithic. Petrography and geochemical data from the archaeological material from Antoliñako Koba")

Turq, A. 1989, Exploitation des matières premières lithiques et occupation du sols: l' exemple du Moustérien entre Dordogne et Lot. In: INQUA: Colloque du comité français de l'Union internationale pour l'étude du quaternaire. Variations des paléo-milieux et peuplement préhistorique, Vol. 13 (Laville, H., Ed.), Cahiers du Quaternaire, CNRS, Bordeaux: p. 179-2014. (in French) ("Lithic raw material exploitation and soil occupation: an example of Mousterian between the Dordogne and Lot") 